\title{
Partial "Global Peace": Federalism and the Long Tail of Remedies in Opioid Litigation
}

Judith Resnik

Follow this and additional works at: https://via.library.depaul.edu/law-review

Part of the Law Commons

\section{Recommended Citation}

Judith Resnik, Partial "Global Peace": Federalism and the Long Tail of Remedies in Opioid Litigation, 70 DePaul L. Rev. 407 (2022)

Available at: https://via.library.depaul.edu/law-review/vol70/iss2/8

This Article is brought to you for free and open access by the College of Law at Digital Commons@DePaul. It has been accepted for inclusion in DePaul Law Review by an authorized editor of Digital Commons@DePaul. For more information, please contact digitalservices@depaul.edu. 


\title{
PARTIAL “GLOBAL PEACE": FEDERALISM AND THE LONG TAIL OF REMEDIES IN OPIOID LITIGATION
}

\author{
Judith Resnik ${ }^{1}$
}

\begin{abstract}
The Opioid Litigation yields important insights for federalism and for remedies in complex multi-party and multi-prong cases. This sprawling set of cases underscores that essentialized ideas of a set of fixed "state" and "federal" interests do not capture the diverse and often conflicting goals of states and subunits or of the national government. Likewise, this litigation serves as a reminder of the need to reframe assumptions about the role courts ought to play when considering settlements aiming "for global peace." Large-scale litigation is often thought to be a two-step process entailing a first decision to aggregate and a second step of either a trial or a settlement. But these forms of lawsuits do not end there. Law needs to clarify that a third step is needed because, even when interests are sufficiently homogenous to warrant aggregation at a litigation's inception and conclusion, differences can emerge thereafter when implementing remedies. Judges should use their authority to ensure that aggregated plaintiffs continue to have access to courts during all three phases of large-scale litigation. Recognition is needed that resolutions are partial because, after liability issues have been resolved, additional information often emerges about the individuals and entities to whom remedies are supposed to flow, and readjustments may be needed in the structure and allocation of relief.
\end{abstract}

1. Judith Resnik, all rights reserved, 2021. Thanks to Stephen Landsman for inviting me to join, to Elizabeth Burch, Zachary Clopton, Abbe Gluck, Alexandra Lahav, and Theodore Rave for insightful analyses that prompted this commentary, and to the other participants in the Clifford Symposium. Wonderful research assistants, past and present, have taught me a lot. Thanks to Urja Mittal and Adela Lilollari for help on this essay. Like others, I have been a participantas a lawyer and court appointee-in some cases related to the issues about which I write. Moreover, this essay builds on my prior related work, as cited throughout, and on a related essay, that was also in press as this one was. See Judith Resnik, Mature Aggregation and Angst: Reframing Complex Litigation by Echoing Francis McGovern's Early Insights into Remedial Innovation, 84 Law \& Contemp. Probs. 231 (2021). 
Three serious papers coming from five authors grapple with courts' roles in the sprawling and complex interactions called the opioid litigation. In their essay, Opioid Cases and State MDLs, Zachary Clopton and Theodore Rave provide a remarkable map of some 430 cases in 48 states that were (as of the spring of 2020) pending outside the hundreds of lawsuits grouped within the federal multidistrict litigation (MDL) involving opioids. ${ }^{2}$ In her essay, MDLs, Federalism, and the Opioid Epidemic, Abbe Gluck examines what she calls "MDL federalism" as she analyzes the interplay among cases and participants in state and federal courts. ${ }^{3}$ In Information for the Common Good in Mass Torts, Alexandra Lahav and Elizabeth Chamblee Burch address the impact of courts on the development and dissemination of information about the marketing of these addictive drugs. ${ }^{4}$ Important insights into litigation, courts, remedies, federalism, and political movements come from thinking about these articles together.

All are court-centric. The authors assume the vitality of courts as important vectors of decision-making in response to the harms of opioids. Even as they worry about limits and pitfalls, they focus on the contributions that courts have, can, and should make. In that sense, they are cheerful accounts. Lahav and Burch detail courts as information generators and disseminators. Clopton and Rave, and Gluck hone in on the struggles for power in the interactions between state and federal courts and among litigants, lawyers, special masters, and judges.

Why - given the many tensions and the underlying tragedy of addiction-call these discussions "cheerful"? Because the institutions at the heart of their inquiry - courts-are under siege. As Clopton and Rave have noted, ${ }^{5}$ I have elsewhere raised concerns about the vulnerability of both state and federal courts on many dimensions. One issue is institutional capture, vividly enacted through heated conflicts over judicial nominations and elections in both federal and state courts. Another problem is the limited funding for state courts. States cannot print money. Moreover, many states are required to have balanced budgets and, sadly, many jurisdictions use courts as revenue centers-

2. Zachary D. Clopton \& D. Theodore Rave, Opioid Cases and State MDLs, 70 DePaul L. Rev. 2 (2021) [hereinafter Clopton \& Rave, Opioid Cases and State MDLs]; D. Theodore Rave \& Zachary D. Clopton, Texas MDL, 24 Lewis \& Clark L. Rev. 367 (2020).

3. Abbe R. Gluck, MDLs, Federalism, and the Opioid Epidemic, 70 DePaul L. Rev. 2 (2021).

4. Alexandra D. Lahav \& Elizabeth Chamblee Burch, Information for the Common Good in Mass Torts, 70 DePaul L. Rev. 2 (2021).

5. See Zachary D. Clopton \& D. Theodore Rave, MDL in the States, 115 Nw. U. L. REv. 2 (2021); see also Clopton \& Rave, Opioid Cases and State MDLs, supra note 2. 
extracting fines and fees from litigants to support local services and, at times, to line some of their coffers. ${ }^{6}$

On top of the morass of efforts to seat certain people as judges, to unseat others who are currently judges, and the struggles of courts for resources comes a third major difficulty: most of the people seeking to use courts have limited resources, and many are poor. In the federal courts, twenty-five percent of all the complaints filed, and fifty percent of all appeals are brought by people who have no lawyers. ${ }^{7}$ In the state courts, estimates are that lawyer-less cases are the norm, including in housing and household disputes. ${ }^{8}$

In contrast, through the papers published in this symposium, we can see what rich litigation looks like. Even as it is hard to account for and to analyze the vast number of filings (and Gluck, Clopton, and Rave do an impressive job of capturing the swirling set of activities), opioid litigation demonstrates what resources can bring to these manypronged disputes. I have long used the image of a Calder mobile for large-scale litigation as one way to underscore that the conventional triangle, typically proffered to depict court-based dispute resolution, does not capture the complex interactions in which participants realign, depending on the issues. Given the price of Calder mobiles, that imagery is particularly apt here.

I bring up the contrast between opioid litigation and the world of poor people, poor courts, and the politics of judicial selection to make a first point: social and political movements are what brought us the many lawsuits that are the subject of this symposium. What we are analyzing exists because, and only because, of innovations that, during the last several decades, changed the litigation landscape. People from various sectors pressed for legal recognition of diverse harms, and courts and legislatures responded. Lawyers and judges as well as legis-

6. See Judith Resnik \& David Marcus, Inability to Pay: Court Debt Circa 2020, 98 N.C. L. Rev. 361, 363 (2020); Judith Resnik, Anna VanCleave, Kristen Bell, Skylar Albertson, Natalia Friedlander, Illyana Green, and Michael Morse, Arthur Liman Ctr. for Pub. Interest Law, Yale Law Sch., Who Pays? Fines, Fees, Bail, and the Cost of Courts (2018).

7. See Judicial Business, tbls.B-19, U.S. Courts of Appeals - Pro Se Cases Filed, by Source (1997-2019), U.S. CourTs, https:/www.uscourts.gov/report-names/judicial-business?tn=B$19 \& \mathrm{pt}=\mathrm{All} \& \mathrm{t}=\mathrm{All} \& \mathrm{~m} \% 5 \mathrm{Bvalue} \% 5 \mathrm{D} \% 5 \mathrm{Bmonth} \% 5 \mathrm{D}=\& \mathrm{y} \% 5 \mathrm{Bvalue} \% 5 \mathrm{D} \% 5 \mathrm{Byear} \% 5 \mathrm{D}=; \mathrm{Ju}-$ dicial Business, tbls.C-13, U.S. District Courts - Civil Pro Se and Non-Pro Se Filings, by District (2004-2019), U.S. CourTs, https://www.uscourts.gov/report-names/judicial-business?tn=C-13 $\& \mathrm{pt}=\mathrm{All} \& \mathrm{t}=\mathrm{All} \& \mathrm{~m} \% 5 \mathrm{Bvalue} \% 5 \mathrm{D} \% 5 \mathrm{Bmonth} \% 5 \mathrm{D}=\& \mathrm{y} \% 5 \mathrm{Bvalue} \% 5 \mathrm{D} \% 5 \mathrm{Byear} \% 5 \mathrm{D}=;$ see also Judith Resnik, Revising Our "Common Intellectual Heritage": Federal and State Courts in Our Federal System, 91 Notre Dame L. Rev. 1831, 1913-14 (2016).

8. Nat'l Ctr. St. Cts., The Landscape of Civil Litigation in State Courts 31-33 (2015). 
latures put into place new rules to enable aggregation of parties and claims. Those conglomerates provide cross-litigant subsidies, economies of scale, and realign power between plaintiffs and defendants. Those procedures are the mechanisms by which causes of action and theories of liability and of remedy get into and stay in courts. ${ }^{9}$

The pressure to aggregate (and hence the shift in nomenclature from "cases" to "litigation") has come from across the spectrum, as aggregation can serve many interests. For example, in the middle of the twentieth century, corporate defendants-such as Central Hanover Bank and Trust-wanted to group together potential litigants because doing so would permit Central Hanover to avoid the risk of thousands of claimants challenging its decisions as a fiduciary. ${ }^{10}$ The famous litigation that resulted-Mullane v. Central Hanover Bank \& Trust-is one example of a quest for "global peace," which has been a longstanding goal of aggregation. That aspiration (wistful, in this chaotic world) is predicated on the assumption that aggregation can bring a wide range of claimants into court and render binding and preclusive judgments.

As Lahav and Burch discuss, what happens in court is presumptively open to the public. Other potential claimants can learn about alleged injuries and, in the words of MDL, "tag along." The window that aggregation can open comes from procedures such as MDLs and class actions (both state and federal) and also because entities-states, municipalities, Indian tribes, and others including Congress (as Ken Feinberg reminded us at the Clifford Symposium with his reference to 9/11) — can also become involved. Many entities and many levels of government have the ability, as do individuals, to seek relief. All these many entities and levels of government have the ability, as do individuals, to seek relief.

The opioid litigation is a vivid example of these many forms of aggregation that facilitate access to courts. My second point is that nobody should take any aspects of access to court-for large or small cases, single-file or aggregated-for granted. Just as social and political movements brought into being various theories of liability, remedies, and procedures exemplified by the opioid litigation, other social and political movements are aiming to cut back on those theories and

9. I have previously documented and analyzed some of this history. See Judith Resnik, From "Cases" to "Litigation", 54 LAw \& Contemp. Probs. 5, 19-20 (1991); Judith Resnik, "Vital" State Interests: From Representative Actions for Fair Labor Standards to Pooled Trusts, Class Actions, and MDLs in the Federal Courts, 165 U. PA. L. REv. 1765, 1780, 1805 (2017) [hereinafter Resnik, "Vital" State Interests].

10. Mullane v. Cent. Hanover Bank \& Tr. Co., 339 U.S. 306, 309-10 (1950). See Resnik, "Vital" State Interests, supra note 9, at 1787-96. 
on the use of courts for remedies and as routes by which information becomes public.

Efforts to limit class actions have been underway since 1966, when Federal Rule 23 was amended to enable more use of aggregation. ${ }^{11}$ Success for those seeking to reduce the use of class actions has come through Supreme Court interpretations of the Rule. ${ }^{12}$ Cutbacks also have come via ex ante prohibitions on aggregate processing for consumers, employees, and purchasers of many services, which the U.S. Supreme Court has upheld by reinterpreting the 1925 Federal Arbitration Act. ${ }^{13}$ In the last decade, as its saliency increased, MDLs have also became embattled in what are sometimes called class action wars.

My third comment is about the breadth of the assault on courtbased decision-making. The thoughtful article by Lahav and Burch analyzes information suppression in courts. In addition, mandates seeking to silence people are becoming commonplace before people use courts or other dispute resolution venues. An example comes from a major credit card company which, last fall, informed all of its customers that:

You and we agree that the arbitration will be confidential. You and we agree that we will not disclose the content of the arbitration proceeding or its outcome to anyone [unless compelled by law]. ${ }^{14}$

This effort to silence arbitration users is, at one level, puzzling because almost no one uses the arbitration process to which such clauses refer. In its 2015 study, the Consumer Financial Protection Bureau found virtually no take up by individuals who might have had claims about their loans and credit card charges..$^{15} \mathrm{~A}$ parallel conclusion comes from data analyses that my students and I did, focused on consumer filings through arbitration against AT\&T. We honed in on AT\&T because it had succeeded in 2011 in the U.S. Supreme Court in

11. See Resnik, From “Cases" to "Litigation," supra note 9, at 9; Resnik, "Vital” State Interests, supra note 9, at 1790-97.

12. Eisen v. Carlisle \& Jacquelin, 417 U.S. 156, 184 (1974); Wal-Mart Stores, Inc. v. Dukes, 564 U.S. 338, 360-61 (2011).

13. AT\&T Mobility LLC v. Concepcion, 563 U.S. 333, 336 (2011); Am. Express Co. v. Italian Colors Restaurant, 570 U.S. 228, 235, 239 (2013); Epic Sys. Corp. v. Lewis, 138 S. Ct. 1612, 1621-32 (2018).

14. That text comes from a form that I received in a letter, sent by American Express and entitled Notice of Important Changes to Your Cardmember Agreement, September 2019. Analyses of the law on clauses aiming to silence users is in Judith Resnik, Stephanie Garlock \& Annie J. Wang, Collective Preclusion and Inaccessible Arbitration: Data, Non-Disclosure, and Public Knowledge, 24 Lewis \& Clark L. Rev. 611, 614 (2020).

15. Consumer Fin. Prot. Bureau, Arbitration Study: Report to Congress, pursuant to Dodd-Frank Wall Street Reform and Consumer Protection Act $\S 1028($ a) 11 (2015). 
enforcing a bar on class actions that it has imposed on its own customers. ${ }^{16}$ We had data to learn about filing rates because some state laws require such information from providers of consumer arbitration services. AT\&T uses the American Arbitration Association (AAA), which complies with that mandate and posts data quarterly. ${ }^{17}$ What we learned from a deep dive into the many web-based entries was that at some points between 2009 and 2017, fewer than thirty individuals sought relief in a given year against AT\&T through the system it had imposed; between 2017 and 2019, on average, 172 individual claims were filed. ${ }^{18}$ During those years, AT\&T had between 85 and 120 million customers. ${ }^{19}$

Given that low incidence of claims, the effort to impose a cone of silence through nondisclosure mandates could be surprising-absent another facet of the data that we examined about consumers' claims. What the filing data show is that, just as in claims involving opioids, aggregation is key; the lack of a ready way to aggregate explains the small number of single-filed claims per year. From the perspective of the entities imposing those mandates, cutting off aggregation has succeeded.

But not completely, as the market in arbitration claims is shifting somewhat, which explains why some companies are not only mandating single-file arbitrations but also adding nondisclosure clauses. Potential defendants aim to lower the visibility of both the disputes and of the means to resolve them. When information is suppressed, others cannot find and follow in the footsteps of the very few who pursue remedies. Moreover, opportunities are dimmed for public oversight of decision-makers and of disputants.

As detailed in the 2020 article, Collective Preclusion, even in smallvalue arbitrations, savvy lawyers and tech groups can create de facto aggregations. Stephanie Garlock, Annie Wang, and I found examples of lawyers and consumer advocates filing a sequence of "individual" claims to create bundles of tens or hundreds and shape de facto aggre-

16. See Concepcion, 563 U.S. at 336. See generally Judith Resnik, Fairness in Numbers: A Comment on AT\&T v. Concepcion, Wal-Mart v. Dukes, and Turner v. Rogers, 125 Harv. L. REv. 78, 102, 112-118 (2011).

17. See, e.g., Cal. Civ. Proc. Code $\$ 1281.96$ (West 2020). To facilitate access to the data, we have created an online open access archive that compiles and preserves quarterly data from the American Arbitration Association. See Teresa Miguel-Stearns, Yale Law School Consumer Arbitration Data Archive (May 23, 2018, 7:58 PM), https://library.law.yale.edu/news/yale-law-schoolconsumer-arbitration-data-archive.

18. See Judith Resnik, Diffusing Disputes: The Public in the Private of Arbitration, the Private in Courts, and the Erasure of Rights, 124 YALE L.J. 2804, 2893-914 (2015).

19. Resnik, Garlock \& Wang, supra note 14, at 627-37 (analyzing the AT\&T data). 
gations. ${ }^{20}$ Under rules of some arbitration providers, such as the American Arbitration Association, the companies imposing mandates to arbitrate are required to pay arbitrators' fees. ${ }^{21}$ Dismayed at the prospect of doing so, some companies sought to escape from the very system that they had obliged their opponents to use. ${ }^{22}$ Thus, in addition to the description of conflicts over aggregation as class action and MDL "wars," the "information wars" that Burch and Lahav ably explore in their analysis are expansive, as illustrated by the example I have provided to augment what Burch and Lahav have discussed.

My fourth comment is that, while I share the views of Burch and Lahav about the import of and the contingency of openness in courts, more about the deployment of information needs to be addressed. We are all in debt to Jeremy Bentham, the great nineteenth-century theorist who celebrated "publicity" as a route to enabling his imagined "Tribunal of Public Opinion" to formulate and pursue welfarist ends. ${ }^{23}$ Yet Bentham not only helped to spawn rights of access to courts and other government activities; his insights were also foundational to the interest in and development of propaganda machines to harness "public opinion" for a variety of ends. Further, while Bentham's imagery was of a single tribunal, as if the public were an undifferentiated whole, that conceptualization is not sustainable in the twenty-first century. Rather than a unified public, we have seen more than vivid evidence of the many publics, and in these times, of riven publics. Moreover, we live in an age that understands information overload and information abuse. Our terms of art include misinformation, disinformation, and false facts. In addition, some members of the many publics use information dissemination to be predatory and exploitative. ${ }^{24}$

Those concerns explain my hesitancy about the focus of Lahav and Burch on "truth seeking." The tasks that adjudication addresses are broader: litigation aims both to understand some of what happened

20. Id. at $617-18,663-67$.

21. Am. Arb. Ass'n, Consumer Arbitration Rules 33-35 (2014); Аm. Arb. Ass'n, Employment/Workplace Fee Schedule: Costs of Arbitration (Nov. 1, 2019).

22. See, e.g., Abernathy v. DoorDash, Inc., 438 F. Supp. 3d 1062, 1066 (N.D. Cal. 2020); see also Michael Corkery \& Jessica Silver-Greenberg, 'Scared to Death' by Arbitration: Companies Drowning in Their Own System, N.Y. TIMEs (Apr. 6, 2020), https://www.nytimes.com/2020/04/06/ business/arbitration-overload.html.

23. Jeremy Bentham, Constitutional Code, in 9 The Works of Jeremy Bentham 377 (John Bowring ed., 1843).

24. See generally Judith Resnik, The Functions of Publicity and of Privatization in Courts and Their Replacements (from Jeremy Bentham to \#MeToo and Google Spain), in Open JusticE: The Role of Courts in a Democratic Society (Burkhard Hess \& Ana Koprivica Harvey eds., 2019). 
that generated a dispute and to find ways to move forward-as the litigation surrounding opioids makes poignantly clear. Courts are potentially generative not only in terms of their ability to provide a retrospective accounting but also in terms of the potential to provide prospective structuring of remedies. Further, as Professors Gluck and Burch explain in another article, MDL Revolution, courts can be innovative. ${ }^{25}$ The range of remedies that can be fashioned reflect legal rules that set forth parameters for bargaining and for adjudication and the ways that participants find to generate new methods of redressing harms.

In the opioid litigation, arguments may exist about who causes which harms, but one premise is shared: the disputants, judges, and the public agree that opioid peddling caused harm. The central questions are how to shape remedies that will be useful and responsive and how to make allocations among claimants. What funds and other services should go to whom for what purposes with what caveats or limits? The conflicts are about the deep and hard underlying problems required to answer those questions and about what entities (including municipalities, states, and federal Indian Tribes, corporate defendants, plaintiffs' lawyers, judges, special masters, and the construct of a "negotiation class" as a surrogate for litigants) have roles in making these decisions.

My fifth comment is a reminder that opioid litigation is, of course, not the only time that the questions about how to manage large-scale conflicts have been asked, albeit not on this scale with this many discrete aggregate and individual claimants. The articles by Gluck and by Clopton and Rave reflect that the landscape of aggregation is "mature" in the sense that examples such as tobacco, phen-fen, emissions, oil spills and more can be found on which to build. New ideas such as a "negotiation class" have been proposed, ${ }^{26}$ yet some of the methods of coordination tried in the past have not been deployed.

I borrow the term "mature" from Frances McGovern, one of the most insightful participants/observers of the development of largescale litigation. Professor McGovern was working on opioid litigation at the behest of the Honorable Dan Polster, the federal district judge assigned to oversee the MDL, when McGovern died unexpectedly in

25. See Abbe R. Gluck \& Elizabeth Chamblee Burch, MDL Revolution, 95 N.Y.U. L. REv. 1 (2021).

26. Francis E. McGovern \& William B. Rubenstein, The Negotiation Class: A Cooperative Approach to Class Actions Involving Large Stakeholders, 99 TEx. L. REv. 73, 78-79 (2020). Judge Polster agreed to use that method, but was reversed by the Sixth Circuit. See In re Nat'l Prescription Opiate Litig., 976 F.3d 664 (6th Cir. 2020). 
2020. Many other judges had turned to Professor McGovern and, some decades ago, he had coined the phrase "mature tort" to argue that aggregation should only occur after many individual cases had been filed and litigated. ${ }^{27}$ McGovern worried that if aggregation occurred "too early" (even as that metric is hard to pinpoint), it could prematurely abort development of issues and the unearthing of requisite information.

Despite the maturity of aggregation in some respects, more modes of coordination are available, and formats used in prior decades have yet to be deployed in opioid litigation. For example, in the 1980s, with the turn to courts for more mass tort actions, state court judges created a consortium - the mass tort litigating committee (MTLC) - to help judges in different jurisdictions coordinate across boundaries. ${ }^{28}$ In 1997, the Federal Judicial Center, the National Center for State Courts, and the State Justice Institute produced the Manual for Cooperation Between State and Federal Courts, providing roadmaps for coordination and insights from participants. ${ }^{29}$

27. Francis E. McGovern, Resolving Mature Mass Tort Litigation, 69 B.U. L. REv. 659, 659 (1989).

28. See Francis E. McGovern, Rethinking Cooperation Among Judges in Mass Tort Litigation, 44 UCLA L. Rev. 1851, 1863-64 (1997); Francis E. McGovern, Toward a Cooperative Strategy for Federal and State Judges in Mass Tort Litigation, 148 U. PA. L. REv. 1867, 1879, 1894 (2000); Byron G. Stier, Resolving the Class Action Crisis: Mass Tort Litigation as Network, 2005 UtAH L. Rev. 863, 917 (2005); Glenn S. Koppel, Toward A New Federalism in State Civil Justice: Developing a Uniform Code of State Civil Procedure Through a Collaborative Rule-Making Process, 58 VAND. L. Rev. 1167, 1199 (2005).

Descriptions come from practice manuals, both state and federal. For example, the Honorable Helen E. Freedman, who was a participant when sitting on the New York State Supreme Court, provided insights in an essay Coordination of Litigation Within New York and Between Federal and State Courts in the New York Practice Series "Commercial Litigation in New York State Courts," co-published by Thomson Reuters and the New York County Lawyers' Association. 3 Robert L. Haig, N.Y. Prac., Com. Litig. in New York State Courts § 18:25 (5th ed. 2020). Judge Freedman wrote:

However, at least one attempt to coordinate among state judges occurred at the time that the Judicial Panel for Multi-District Litigation (JPML) decided in 1991, after six prior applications had been rejected, to coordinate the asbestos litigation for cases filed in federal courts. A number of state judges, correctly anticipating that most new asbestos cases would then be brought in state courts, established a state Mass Tort Litigation Committee (MTLC) under the aegis of the Conference of Chief Justices to discuss techniques for managing asbestos cases. Using the good offices of Professor Francis E. McGovern, MTLC obtained funding that would last for about five years from the State Justice Institute. The National Center for State Courts administered the State Justice Institute grant and handled logistical arrangements enabling the judges to meet with each other periodically in different cities. Although it was originally an asbestos litigation committee, the Committee's functions expanded to include other mass torts. Id.

29. James G. Apple, Paula L. Hannaford, \& G. Thomas Munsterman, Manual for Cooperation Between States and Federal Courts (1997). As they explained: 
In the late 1980s and 1990s, the Honorable Sam Pointer, who was the MDL judge for In re MDL Breast Implant, shaped a set of connections with these state court judges. Sitting in the federal court in Alabama, Judge Pointer interacted on a regular basis with more than two dozen state court judges from that many jurisdictions. ${ }^{30}$ Further, Judge Pointer set up a structure to have some control over all of the attorneys involved in the MDL; he required contributions to what was termed the "common benefit fund" to fund joint discovery and support the structure for proceeding on behalf of the group in the MDL. ${ }^{31}$

Other parallels from the past decades involve federal and state judges who coordinated and, at times, literally sat together in the same courtroom. At one point in the Brooklyn Navy Yard Asbestos Litigation, Judge Jack Weinstein of the Eastern District of New York and Justice Helen Freedman in New York State's Supreme Court issued one opinion with two captions, one for each of their jurisdictions, and the ruling went into the docket of both jurisdictions. ${ }^{32}$ An example of joint settlement work comes from litigation involving the collapse of a hotel skywalk in Connecticut. Judge Robert Zampano of the U.S. Dis-

The Mass Tort Litigation Committee (MTLC), a standing subcommittee of the Conference of Chief Justices, serves as the state counterpart to the federal JPML. Although it lacks the authority to command state courts to engage in coordinated pretrial activities, the MTLC accomplishes some of the same tasks as the JPML by facilitating voluntary cooperation among state courts. In addition to active involvement in ongoing cases (e.g., coordinating discovery and trial schedules), the MTLC acts as a communication and information network, developing performance standards and standardized procedures for managing complex litigation. It also advises state and federal organizationse.g., the U.S. Congress and the Conference of Chief Justices-about the jurisdictional issues implicated by complex litigation. As these parallel efforts have been increasingly formalized in the respective judicial systems, state and federal courts are now advancing to the next logical stage of state-federal coordination of multijurisdictional litigation: the development of formal intersystem coordination.

Id. at 31. See also Nat'l Jud. C., Resource Guide for Managing Complex Litigation (2010); Fed. Jud. Ctr., Nat'l Ctr. St. Cts., Coordinating Multijurisdiction Litigation: A Pocket Guide for Judges (2013) [hereinafter Coordinating Multijurisdiction Litigation].

30. In re Silicone Gel Breast Implants Prods. Liab. Litig., 887 F. Supp. 1463 (N.D. Ala. 1995). See, e.g., Coordinating Multijurisdiction Litigation, supra note 29, at 10 (discussing joint Daubert hearings in federal and state court); Apple, Hannaford, \& Munsterman, supra note 29, at 128 (listing comprehensive case-management orders for consolidated cases).

31. Order No. 27 (Approval of Revised Settlement Program and Injunctions), In re Silicone Gel Breast Implants Prods. Liab. Litig., No. 92-P-10000-S (N.D. Ala. Dec. 22, 1995) (on file with the author).

32. See In re E. \& S. Dists. Asbestos Litig., 772 F. Supp. 1380, 1384 (E.D.N.Y. 1991); William W. Schwarzer, Nancy E. Weiss \& Alan Hirsch, Judicial Federalism in Action: Coordination of Litigation in State and Federal Courts, 78 VA. L. Rev. 1689, 1705 (1992); Asbestos Litigation Crisis in Federal and State Courts: Hearings Before the Subcomm. on Intellectual Prop. and Judicial Admin. of H. Comm. on the Judiciary, 102d Cong. 34-35 (1992) (statement of Helen Freedman, JJ., New York Supreme Court). 
trict Court of Connecticut and Judge Frank Meadow of Connecticut's Superior Court joined together in working with lawyers to shape settlements embracing cases in state and federal court. ${ }^{33}$

I am not suggesting that such coordination is easy. Moreover, it raises several questions, including whether parties should have access to information exchanged outside their presence among the judges and whether federal judges could have undue authority over cases not "in" their jurisdiction. Yet another issue of great saliency to lawyers is the sources of power through MDL that Judges Pointer and Weinstein exercised to organize cost and fee allocations, all in an era before Rule 23 authorized judges to superintend class action attorney selection and fees. ${ }^{34}$

What these examples underscore is that more alternatives in this federal system are available than have been utilized thus far in the opioid litigation. Whether sets of judges, lawyers, and litigants could have found a path to coordination, I do not know. Indeed, even as the actors in these cases are often (as Elizabeth Burch has written ${ }^{35}$ ) repeat players with a good deal of experiences in other cases, Clopton and Rave introduce us to some new participants-law firms working on state cases and not double dipping in the federal MDL. Clopton and Rave argue that these separate lawyers are one of the reasons why state cases can provide counterweights and complicate the power asserted by national actors. Moreover, as Gluck recounted at the symposium, Judge Polster's orders referenced coordination, where a shared document and discovery depository was created; yet the work was not formulated as a joint endeavor and, within short order, Gluck reported, defectors emerged who withdrew as a myriad of litigants and their lawyers jockeyed over authority and sequencing. ${ }^{36}$ Even if the hurdles were and are enormous, "mature" aggregation in this federation includes this array of methods for dispute resolution in addition to a federal MDL and litigation in state courts, in and outside of state MDLs.

33. Sam Howe Verhovek, Pact Reached In Collapse Of Building, N.Y. Times (Nov. 16, 1988), https://www.nytimes.com/1988/11/16/nyregion/pact-reached-in-collapse-of-building.html.

34. See Order No. 13A (Modifying Amount of Common Benefit Fund Assessment), In re Silicone Gel Breast Implants Prods. Liab. Litig., No. CV 92-10000-S (N.D. Ala. Dec. 28, 1999); In re Agent Orange Prod. Liab. Litig., 818 F.2d 145 (2d Cir. 1987).

35. See generally Elizabeth Chamblee Burch, Mass Tort Deals (2019).

36. See Gluck, supra note 3; Protocol for State and Federal Court Coordination, In re Nat'l Prescription Opiate Litig., No. 1:17-md-2804 (N.D. Ohio Oct. 9, 2018) (Doc. No. 1029); Order Establishing Deposition Protocol, In re Nat'l Prescription Opiate Litig., No. 1:17-md-02804-DAP (N.D. Ohio June 20, 2018) (Doc. No. 643). 
My sixth comment is that, in addition to prompting questions about how to build in a broader repertoire in "mature" aggregation through experiments in joint venturing among subsets of judges, the Gluck and Clopton/Rave papers underscore an important aspect of federalism discourse that is not sufficiently appreciated. Many discussions of federations presume a singularity of entities - the federal government and the states. The U.S. Supreme Court supports that impression as it sometimes justifies judgments by invoking federalism, as if saying that word suffices to justify a given decision. At both a descriptive and a normative level, this framing is misguided.

Federalism is a way to organize governments in which subunits have degrees of autonomy and participation, even as the larger unit has authority in some instances to impose norms. ${ }^{37}$ But to think of the larger and smaller units as having fixed interests is to miss the dynamic aspects of federations. If ever we needed a reminder, Gluck's account of the fissures among states and within any one state underscores that such jurisdictional "essentialism" does not work as a descriptive matter, nor is it normatively desirable. ${ }^{38}$ Preferences are neither exogenous nor static but formed through interactive and multifaceted exchanges.

Furthermore, the autonomy in identification of interests by subunits is often overstated. To conceptualize states, cities, Indian tribes, and other subunits as lone rangers, in sui generis acts of self-rule, is to miss that their lawmaking, even when claimed to be constitutive of a particular locality's identity, is embedded in and related to translocal and transnational social movements. Agreements across subunits within a given federation (sometimes termed "horizontal federalism" 39 ) are increasingly commonplace, as are translocal-transnational accords in which subunits of more than one federation co-venture with each other across national boundaries.

The infrastructure that predated opioid litigation includes national private organizations of public actors-for example, the U.S. Conference of Mayors, the National League of Cities, the National Association of Attorneys General, and many more. These translocal

37. The literature is of course vast. One cross-national overview of the constituent elements of federalism comes from Andreas Auer, The Constitutional Scheme of Federalism, 13 J. Eur. PuB. PoL'y 419 (2005).

38. See Gluck, supra note 3. See also Judith Resnik, Federalism(s)' Forms and Norms: Contesting Rights, De-essentializing Jurisdictional Divides, and Temporizing Accommodations, 55 NOMOS: FedERALISM \& Subsidiarity 363 (2014).

39. See, e.g., Gillian E. Metzger, Congress, Article IV, and Interstate Relations, 120 HARv. L. Rev. 1468 (2007); Lynn A. Baker, Putting the Safeguards Back into the Political Safeguards of Federalism, 46 VILL. L. Rev. 951, 956, 961-66 (2001). 
organizations of governmental actors (TOGAs) gain power because their membership is linked to particular public positions held. ${ }^{40}$ TOGAs are both norm entrepreneurs and information distributors. They are paralleled by associations of private actors, such as a variety of specialized bars and organizations, often going under the term "special interest groups."

Opioid litigation is a case study of why a flat account of federalism-that presumes it has a singular normative content, that state interests can be readily aggregated, and that national interests are fixed-misses the mark. Indeed, even as opioid litigation is claimed to be distinctive, on this dimension it is familiar. In major "federalism" cases in the U.S. Supreme Court-from United States v. Lopez and United States v. Morrison to Obergefell v. Hodges-states and subunits filed amici briefs on opposing sides. ${ }^{41}$ Thus, when in each instance, the Court reported that its decision was influenced by federalism, the Justices in the majorities were choosing which of those competing claims about federalism to credit. ${ }^{42}$

Throughout the history of the United States, and likely true in other federations, power has not moved only in one direction; rather it can flow back and forth as well as diagonally. Moreover, the resolutions produced by institutional mediators (be they courts or other branches of government, political parties, or private sector actors) are frequently temporizing, as contestation and negotiations continue despite (and sometimes because of) court rulings or agreements. As a result, what seems to have been settled through constitutional adjudication or political negotiations may be reconfigured. This production and reproduction of conflict is why I used the term "partial peace" in the title of this commentary.

I have thus far focused on the lessons to be gleaned from opioid litigation about class (as in economic strata) in courts, about aggregation as a key kind of subsidy, about the uses and abuses of information, and about the interactions among court systems within the federal system of the United States. I close by examining how the opioid litigation provides reasons to be skeptical about the desirability

40. Judith Resnik, Joshua Civin \& Joseph Frueh, Ratifying Kyoto at the Local Level: Sovereigntism, Federalism, and Translocal Organizations of Government Actors (TOGAs), 50 ARIZ. L. REv. 709, 731-32, 740-58 (2008) (discussing more of these organizations and their agendas).

41. United States v. Lopez, 514 U.S. 549 (1995); United States v. Morrison, 529 U.S. 598 (2000); Obergefell v. Hodges, 576 U.S. 644 (2015).

42. Judith Resnik, Judging Methods of Mediating Conflicts: Recognizing and Accommodating Differences in Pluralist Legal Regimes, in Judicial Power: How Constitutional Courts Affect Political Transformations 250 (Christine Landfried ed., 2019). 
of questing for forms of "global peace" that depend on court judgments and settlements having broad preclusive impact.

To explain, I draw on an argument I made in Reorienting the Process Due, written for a symposium that marked the 50th anniversary of the 1966 amendments to the class action rule. ${ }^{43}$ As I explained there, we have learned through the maturity of aggregation requires rethinking the structure that Rule 23 created in 1966 for class actions. When inventing that rubric, the drafters worried about the legitimacy of representative actions. For them, "homogeneity of interests" was the touchstone, ${ }^{44}$ and their examples included customers overcharged by a utility and children in segregated schools.

Confident in the ability of judges to identify when interests were sufficiently aligned to permit group-based litigation, the drafters outlined how judges ought to assess requests for certification at the outset (under Rule 23 (a) and (b)) and then for settlement under 23 (e), when the drafters required judges to reaffirm the propriety of class treatment. That two-step template recognized that the interests of individuals grouped through aggregation were not necessarily fixed over the lifespan of a litigation. The 1966 Rule 23 therefore required judges to interrogate the homogeneity of interests at the time of certification and then to return to that question at settlement. That is the "twostep" process that I referenced in the abstract of this essay.

Amendments in 2003 expanded the role of judges at certification and at settlement by charging them with appointing counsel for the class, by outlining rules for the award of attorneys' fees, and by enlarging the possibilities for interlocutory appeals. ${ }^{45}$ A robust body of law from district and appellate courts bears testament to courts' efforts to discharge these obligations. Amendments in 2018 again wrote

43. Judith Resnik, Reorienting the Process Due: Using Jurisdiction to Forge Post-Settlement Relationships Among Litigants, Courts, and the Public in Class and Other Aggregate Litigation, 92 N.Y.U. L. Rev. 1017, 1017-18, 1020-22 (2017).

44. (Preliminary Memorandum) Modifications of the Provisions for Class Actions, appended to Tentative Proposal to Modify Provisions Governing Class Actions-Rule 23, at EE-11 n.5 (dated in Congressional Information Services (CIS) compilation as May 28-30, 1962), at CIS No. CI-6309-44. The memorandum was referenced in a related memo, "Class Actions-Some Further Thoughts," which has a handwritten note "August 1962," at its top; the Further Thoughts memo noted that the Modifications memo had been provided in advance of the May 28-29, 1962 meeting of the Advisory Committee of Civil Rules, drafting Rule 23. See Class Actions-Some Further Thoughts 1 (Aug. 1962), from the papers of Professor Kaplan archived in the Historical and Special Collections of the Harvard Law Library, at Box 75, folder 5 in the Benjamin Kaplan Papers, 1939-2010, at the Historical and Special Collections of the Harvard Law Library (copies on file with the author).

45. See FED. R. Civ. P. 23(f)-(h). 
more detail into the contours of oversight at settlement. ${ }^{46}$ But Rule 23 falls silent thereafter. As currently drafted, the Rule places no obligations for judges to oversee the remedies provided through settlements, to deal with disputes that may arise, or to require public accountings for what transpires. ${ }^{47}$

Opioid litigation is a powerful example of why "homogeneity of interests" is not a term that captures the lived experiences of the many plaintiffs, what they want for the future, or how that future will play out. The problems are not only how much money to allocate to whom but also how to generate remedies in a diverse country and within states, municipalities, counties, and Indian tribes, and in urban and rural settings with vastly different healthcare facilities and resources, density of population, and wealth.

Through their power to delineate aggregates and bring litigants together in multi-party litigation, courts set the boundaries of negotiations and of trials. Judges hold the power to issue judgments that are binding, and judges can use their authority to build into those settlements and judgments opportunities for oversight and the possibility of reconsideration. Illustrations in the contemporary world of decisions that are binding but do not close off future discussions in court come from family law. Rulings on child custody and on support are based on the age of children and family circumstances, which can change, and hence, parties can return to court for adjustments and reconsideration. On the criminal side, the writ of habeas corpus recognizes the potential (rare under current doctrine and statutes) that judges need to revisit convictions and sentences. Civil rights injunctions are another example as the U.S. Supreme Court has crafted a distinctive approach to modification of injunctions, ${ }^{48}$ and Congress has built into prison conditions litigation end points and the possibility of reconsideration. ${ }^{49}$

Those examples serve as reminders that preclusion of subsequent litigation is a legally crafted doctrine that can be reconfigured to respond to the needs of particular kinds of litigants, and it varies with

46. See FED. R. Civ. P. 23(e)(2)(ii), as amended in 2018 to provide a list of factors to consider for evaluating settlements and including "the effectiveness of any proposed method of distributing relief to the class, including the method of processing class-member claims ..."

47. Some districts do make reference to these issues in their local rules. See, e.g., Procedural Guidance for Class Action Settlements, U.S. Dist. Ст. N. DisT. CA., https:// www.cand.uscourts.gov/ClassActionSettlementGuidance (last updated Dec. 5, 2018).

48. See Rufo v. Inmates of Suffolk Cty. Jail, 502 U.S. 367, 398 (1992); Horne v. Flores, 577 U.S. 433, 471-72 (2009).

49. Prison Litigation Reform Act, Pub. L. No. 104-134, § 801 (codified at 42 U.S.C. $§ 1997$ e (2012)). 
subject matters. Further, while not often part of the current discussion of class actions, in the early 1960s, the drafters of Rule 23 considered not making all determinations final. Rather, they debated whether that rule ought to require notice (or not) to those affected and whether it could bind one side and preclude only the defendant in a class action from subsequently contesting the first ruling. ${ }^{50}$

Indeed, in the 1940s, after Congress created a means to bring a representative action under the Fair Labor Standards Act (FLSA), ${ }^{51}$ federal judges required individuals to intervene (through filing letters or otherwise) because those lower courts thought they had to; their opinions explain that they assumed it would be unconstitutional to bind people who had not personally acknowledged that they wanted to be represented by the employees who had stepped forward. ${ }^{52}$ In contrast, since 1966, we have taken for granted the proposition that courts have the capacity to bind absentee plaintiffs if judges certify the representation to be adequate and if notice was provided to at least a subset of those to be bound..$^{53}$

What the framers of Rule 23 did not focus on is what happens once settlements are entered in the classes that they licensed. What we have learned from more than six decades of aggregation through class actions and MDLs is that it is not "over" when it is "over." Settlements do not end cases for aggregates because most remedies have long tails. This proposition is familiar to those focused on civil rights and prisoner class actions, which regularly rely on special masters and compliance monitors and on trips to court to implement or to modify decrees.

Parallels to the post-decision litigation in structural public law litigation exist in cases ending with monetary relief, as a variety of postdecision actors are needed to put remedies into place. Judges have sprouted a host of auxiliary personnel with a range of titles such as monitors, masters, and escrow agents as well authorized specially-designed claims facilities. Yet their work has been subjected to less pub-

50. See Resnik, "Vital” State Interests, supra note 9, at 1793 (explaining in detail the memos exchanged discussing whether to bind absentees).

51. Fair Labor Standards Act of 1938, Pub. L. No. 75-718 §16(b), 52 Stat. 1060, 1069 (codified as amended at 29 U.S.C. $\$ \S 201-19)$.

52. See, e.g., Wright v. U.S. Rubber Co., 69 F. Supp. 621, 624 (S.D. Iowa 1946); Shain v. Armour \& Co., 40 F. Supp. 488, 490 (W.D. Ky. 1941). See Resnik, "Vital” State Interests, supra note 9 , at $1785-86$.

53. A few dissenters, arguing that class actions raise due process problems, exist. See, e.g., Martin H. Redish, Wholesale Justice: Constitutional Democracy and the Problem of the Class Action Lawsuit 5-8 (2009); Martin H. Redish, The Liberal Case Against the Modern Class Action, 73 Vand. L. Rev. 1127 (2020). 
lic scrutiny than in the civil rights injunction context. One reason is that defendants seeking economic closure have few incentives to raise questions about the distribution of remedies. In some cases, only small subsets of plaintiffs recoup, either because of a lack of information, or the time and effort required to do so are greater than the likely recovery or that the information demanded to receive payment is not easily available. Yet not all of the difficulties that could occur in disbursement may be understood at the time that settlements are crafted and approved.

In her comments, Abbe Gluck pointed out the many health problems that stem from opioid use and the need to attend to them. Remedies in terms of money need to address not only the amount paid but also at what intervals and, when paid to aggregates such as localities, whether any methods to organize how the funds are spent should be built into agreements. When opioid cases are adjudicated or settled, remedies will have to be structured to respond. Again, illustrations come from prior mass torts. For example, heart valve product defect lawsuits resulted for a time in medical monitoring remedies. ${ }^{54}$ The Agent Orange settlement included some social services for veterans. ${ }^{55}$

In terms of imposing duties on plaintiffs' counsel to do post-settlement distribution work, the Honorable Vince Chhabria, sitting in the Northern District of California, provides an example of efforts to do so. In a few cases, he has structured an ongoing relationship between the litigants to the court. In a class action settlement brought by Lyft employees, Judge Chhabria required, as a condition of his approval of the settlement, a series of post-settlement accountings to be filed with the court. ${ }^{56}$ In one such order, plaintiffs' counsel was instructed to

54. For example, in one such case, the Eighth Circuit rejected a district court decision to create a subclass for medical monitoring. See In re St. Jude Med., Inc., 425 F.3d 1116, 1123 (8th Cir. 2005). Thereafter, the Eighth Circuit decertified the class. See In re St. Jude Med., Inc., 522 F.3d 836, 841-42 (8th Cir. 2008). See generally James A. Henderson, Jr. \& Aaron D. Twerski, Asbestos Litigation Gone Mad: Exposure-Based Recovery for Increased Risk, Mental Distress, and Medical Monitoring, 53 S.C. L. REv. 815, 837 (2002); Kenneth S. Abraham, Liability for Medical Monitoring and the Problem of Limits, 88 VA. L. REV. 1975, 1976 (2002).

55. In re Agent Orange Prod. Liab. Litig., 597 F. Supp. 740,859 (E.D.N.Y. 1984), aff'd, 818 F.2d 145, 174 (2d Cir. 1987).

56. See Order Requiring Notice of Completion of Duties, Cotter v. Lyft, Inc., No. 13-cv-04065VC (N.D. Cal. April 6, 2018). The lawyers for the plaintiffs have submitted, and the court has approved, a Notice of Completion of Duties. See Order Approving Notice of Completion of Duties, Cotter v. Lyft, Inc., Case No. 13-cv-04065-VC (N.D. Cal. May 6, 2019) (Doc. No. 371). Judge Chhabria has also issued other related orders. See Related Case Order, Brunner v. Lyft, Inc., No. 19-cv-04808-WHA (N.D. Cal. Sept. 6, 2019) (Doc. No. 373); Related Case Order, Rogers v. Lyft, Inc., No. 20-cv-01938-YGR (N.D. Cal. Mar. 23, 2020) (Doc. No. 376); Related Case Order, Norton v. Lyft, Inc., No. 19-cv-02025-EMC (N.D. Cal. May 6, 2019) (Doc. No. 370). 
provide the judge with a "notice of completion of duties," to be filed after the final distribution of payments, and to include the total amount distributed, the number of class members to whom payments were sent, the amounts paid, the checks cashed, and discussion of the issues that had arisen. ${ }^{57}$ In another, dealing with a class of potentially more than three million people challenging the charges imposed for some fifteen years by Wells Fargo for opening unauthorized accounts, Judge Chhabria issued what was styled an "order granting final approval, service awards, and attorneys' fees" that approved the establishment of a $\$ 142$ million fund. That order directed that, "[w]ithout affecting the finality of this Judgment, the Court reserves jurisdiction over the Class Representatives, the Settlement Class, and Defendants as to all matters concerning the administration, consummation, and enforcement of the Settlement Agreement." 58

Another example comes from Sundquist v. Bank of America, where a California bankruptcy judge awarded what Catherine Sharkey has described as "an eye-catching $\$ 45$ million in punitive damages against Bank of America for egregious misconduct directed at a couple in foreclosure proceedings, but, after awarding $\$ 5$ million to the couple, directed the remainder of the punitive award to entities that fight financial abuse and champion vulnerable victims." 59 In short, through a variety of mechanisms, judges can require as part of the approval of multi-party settlements that mechanisms for monitoring, reporting, and opportunities for adjustments of remedies be put into place.

I have provided these illustrations to underscore that settlements of consumer and mass tort lawsuits involve a range of remedies that can be challenging to implement, and that during this third phase of aggre-

57. $I d$

58. Jabbari v. Wells Fargo \& Co., 2017 WL 5157608 (N.D. Cal. 2017); Revised Order Granting Final Approval of Class Action Settlement, Approving Service Awards, and Awarding Attorneys' Fees and Expenses II 42, Jabbari v. Wells Fargo \& Co., No. 15-cv-02159-VC (N.D. Cal. June 14, 2018), ECF No. 271. Moreover, the order stated:

The exclusion request submitted by the Navajo Nation shall be effective as to claims asserted in the Navajo Nation's own proprietary interests, but does not effectuate an exclusion of individual members of the Navajo Nation from the Settlement Class nor does it limit any res judicata effect this Judgment has on the claims the Navajo Nation has asserted, or may in the future assert, to protect the interests of members of the Navajo Nation . . . Indeed, to do so would infringe on the due process rights of the individual class members, who have the right to intelligently and individually choose whether to continue in a suit as class members.

Id. II 21.

59. Catherine M. Sharkey, Punitive Damages Transformed into Societal Damages, in Punishment and Private Law (Elise Bant, Wayne Courtney \& Jeannie Paterson eds., 2021) (discussing Sundquist v. Bank of Am., N.A., 566 B.R. 563 (Bankr. E.D. Cal. 2017), vacated in part sub. nom., In re Sundquist, 580 B.R. 536 (Bankr. E.D. Cal. 2018)). 
gate litigation, new information may come to light after the lawsuit has, in only one sense, concluded. The question of the homogeneity of interests within an aggregate exists across the lifespan of aggregations, and that lifespan includes post-settlement implementation. Instead of using (as aggregation's critics propose ${ }^{60}$ ) some of these difficulties of implementation, the emergence of conflicts, and low claims rates in certain cases as the bases on which to preclude class certification, aggregate settlements need to build in acknowledgement of the complexities of making remedies effective.

Just as the class action rule aimed in the 1960s to provide crossplaintiff subsidies during the pre-judgment phases of litigation, the rule and practices under all forms of aggregation can be retooled to shape methods of generating group-based participatory rights and public debates during this third phase. Even if, as David Shapiro suggested, the class is best understood as "an entity" (rather than as an aggregation of individuals) before resolution, ${ }^{61}$ the issue of regrouping of interests (and sometimes of disaggregation) needs to be considered during the remedial phase to learn whether once homogenous and adequately represented interests diverge on the form relief takes. ${ }^{62}$ Moreover, whether discord emerges or not, court oversight is needed post-judgment to ensure distributional fairness and to facilitate public access to the processes and outcomes of these large-scale cases.

Doing so requires opening the door to post-resolution assessment (and sometimes readjustments) in court. Judges need to retain authority during this third remedial phase of aggregation and can do so expressly, as illustrated in my discussion of the Wells Fargo and Lyft settlements. The law of personal jurisdiction relies on defendants affirmatively affiliating with a forum; the law of post-settlement aggregation needs to build mechanisms to maintain affiliations between litigants and the courts, and to make such relationships part of the public practices of courts. The result would reflect the realities of distinctions among sets of individuals with overlapping, albeit not al-

60. Such arguments are analyzed in Geoffrey C. Shaw, Class Ascertainability, 124 YALE L.J. 2354 (2015).

61. David L. Shapiro, Class Actions: The Class as Party and Client, 73 Notre Dame L. Rev. 913, 917 (1998).

62. The focus of this essay is on the United States. The use of aggregate litigation elsewhere includes examples of some forms of oversight. In Australia, distribution of funds pursuant to representative proceedings that are settled entail a court-approved settlement distribution plan-a settlement distribution scheme ("SDS"), and some courts have developed rules on oversight. See Rebecca Gilsenan \& Michael Legg, Australian Class Action Settlement Distribution Scheme Design-Deciding Who Gets What, 38 U. QLD. L.J. 15, 15 (2019). 
ways homogenous, interests. Litigation systems bundle them together because, as one English jurist described more than a century ago, it was "better to go as far as possible toward justice than to deny it altogether." 63

An elaboration of this third phase of aggregate litigation would respond to the pragmatic needs that have always driven class action design. It would also reflect the substantive due process concerns found in the recent law of personal jurisdiction about how to make courts into "homes" for litigants. ${ }^{64}$ Structuring law and settlements to generate connectedness for absent litigants throughout the phases of class actions underscore the interdependencies of litigants across the jurisdictions within the federation.

Therefore, instead of aspiring for "global peace," the parties and the court ought to acknowledge what is an impressive achievementobtaining "partial peace," even as information remains insufficient to close the door on all kinds of reconsideration, in terms of the forms of relief provided, its recipients, and its allocation. Post-settlement disagreements would therefore not be "collateral to" but part of the initial litigation. Many parameters of an agreement can be set but not sealed as aggregations end their second phase.

In terms of concerns about spawning "multiple bites at the litigatory apple" (as the D.C. Circuit raised when fashioning a common law doctrine of virtual representation ${ }^{65}$ ), the Supreme Court's Taylor $v$. Sturgell decision (reversing that ruling) provides a model of inquiry into the identity of interests between any new claimants and the original litigants. ${ }^{66}$ The certification of the adequacy of representation at a class action's inception, consolidation, or via MDL treatment would create presumptions that the results achieved in a settlement should

63. Duke of Bedford v. Ellis [1901] AC 1, 8 HL. Chafee discussed this case in his book. See Zechariah Chafee, Jr., Some Problems of Equity 215-16 (1950).

64. See, e.g., Bristol-Myers Squibb Co. v. Super. Ct. Cal., 137 S. Ct. 1773, 1776 (2017); Daimler AG v. Bauman, 571 U.S. 117, 126 (2014); Goodyear Dunlop Tires Operations, S.A. v. Brown, 564 U.S. 915, 919 (2011); BNSF Ry. Co. v. Tyrrell, 137 S. Ct. 1549, 1559 (2017); RJR Nabisco, Inc. v. European Cmty., 136 S. Ct. 2090, 2115 (2016) (Ginsburg, J., dissenting); Jesner v. Arab Bank, PLC, 138 S. Ct. 1386, 1430 (2018) (Sotomayor, J., dissenting). See generally Richard D. Freer, Some Specific Concerns with the New General Jurisdiction, 15 NEV. L.J. 1161, 1166 (2015).

65. Taylor v. Blakey, 490 F.3d 965, 975 (D.C. Cir. 2007) (internal quotation marks omitted), rev'd sub nom., Taylor v. Sturgell 553 U.S. 880 (2008).

66. The Court there refused a federal common law rule that would have added new grounds for preclusion. Instead, it reiterated its adherence to the "fundamental nature of the general rule that a litigant is not bound by a judgment to which she was not a party." Sturgell, 553 U.S. at 898 . The Court imposed parameters on the permissible forms of preclusion: preclusion can only occur if "at a minimum ... [ $\mathrm{t}$ ] he interests of the nonparty and her representative are aligned" and "either the party understood herself to be acting in a representative capacity or the original court took care to protect the interests of the nonparty." Id. at 900. 
remain in place. Yet that settlement ought not to be read as flatly preclusive if new issues emerge after settlement that require adjudication. ${ }^{67}$

Courts approving settlements should be seen as an aggregate's home base, exercising jurisdiction "by necessity" 68 that permits litigants to return post-settlement as part of-rather than collateral tothe original litigation. Thus, class and other aggregate settlements would include notice to absentees of their right to proceed in public if they can identify structural concerns. Doing so ought not to be viewed as noxious "multiple bites at the litigatory apple," 69 but as occasions to address whether the judgment of a settlement as fair, just, and adequate that was made when the case was settled withstands subsequent developments or whether adjustments are needed to implement the remedies.

To make this third phase workable, the incentives of the parties, the lawyers, and the judges need to be addressed. At the outset, I cited the high number of unrepresented civil litigants. Those statistics are reminders that procedural aspirations need to be accompanied by resources to use them. Work during this third phase needs to recognize whether efficient modes of distribution exist and how to create incentives for all the lawyers to remain actively involved.

For example, judges using MDL as well as class actions could commend that, in appropriate cases, they meet regularly (and presumptively on the record) after settlements have been approved with all the parties' lawyers to learn about barriers to recovery. Further, judges could refuse to endorse settlements that do not entail set-aside funds to pay the time of plaintiffs' lawyers for implementation work, unless defendants use their best efforts to implement remedies.

The relevant lawyers are not only those on the leadership team for the aggregation but also individually retained plaintiffs' attorneys filing the cases initially (IRPAs, as Dennis Curtis, Deborah Hensler, and I once called them ${ }^{70}$ ). When IRPAs are involved and if individualized

67. Another exemplar comes from Rule 60(b) of the Federal Rules of Civil Procedure, providing that when new information that "with reasonable diligence could not have been discovered" at the relevant time (here settlement, rather than trial), judges may provide some form of relief from judgment. FeD. R. CIV. P. 60(b)(2).

68. See George B. Fraser, Jr., Jurisdiction by Necessity-An Analysis of the Mullane Case, 100 U. PA. L. Rev. 305, 319 (1951).

69. Taylor v. Blakey, 490 F.3d 965, 975 (D.C. Cir. 2007) (internal quotation marks omitted), rev'd sub nom., Taylor v. Sturgell, 553 U.S. 880 (2008).

70. Judith Resnik, Dennis E. Curtis, \& Deborah R. Hensler, Individuals Within the Aggregate: Relationships, Representation, and Fees, 71 N.Y.U. L. REv. 296, 300 (1996). See, e.g., In re Thirteen Appeals Arising Out of the San Juan Dupont Plaza Hotel Fire Litig., 56 F.3d 295, 300 (1st 
work is needed ${ }^{71}$ structured fee awards could link payments to IRPAs for client-centered work done to implement remedies. In short, rather than assume that the delineation between the aggregate as an "entity" or a combination of individuals remains stable over a litigation's lifespan, the frame may shift. The "entity" approach may dominate presettlement and dis-aggregation may be needed to create more individualization after settlement.

Another set of lawyers not sufficiently in focus are those representing defendants, presumed to walk away after the settlement parameters have been approved or a court-ordered remedy announced. Instead of seeing implementation as solely the province of plaintiffs' lawyers, courts can fashion obligations for defendants to cooperate and, when possible, lower transaction costs of distribution. Post-settlement accountings could come from defendants as well as plaintiffs, again to reflect the ongoing activities during the third phase.

Before closing, I need to address what I see to be the good to be produced by the potential for more disputes and more work for courts and lawyers. The under-documented and under-regulated set of interactions among lawyers, clients, court-authorized auxiliary personnel, and sometimes judges need to be brought within the fold of the mix of constitutional values and common decency that animated the drafting of the original Rule 23, the 1966 revisions, and MDLs. Distributional debates inside a claims resolution system should not be left to the private decision-makers authorized under such settlements without a subsequent opportunity for a return to public courts.

Furthermore, and to return to the concerns that animate Lahav and Burch's article, due process property rights are not the only relevant constitutional touchstone. A line of cases recognizes a First Amendment right to have access to government proceedings from criminal to civil litigation..$^{72}$ Yet, lower courts have debated, for example, whether reports by monitors appointed to oversee injunctions are "judicial

Cir. 1995); In re Nineteen Appeals Arising Out of San Juan Dupont Plaza Hotel Fire Litig., 982 F.2d 603, 605 (1st Cir. 1992).

71. See Order Denying Non-Class Counsel's Motions for Attorneys' Fees at 1, In re Volkswagen "Clean Diesel” Mktg., Sales Practices, \& Prods. Liab. Litig., 2017 WL 1474312 (N.D. Cal. Apr. 24, 2017). Judge Charles Breyer denied "244 motions for attorneys' fees and costs filed by attorneys who did not serve as Class Counsel . . . [b]ecause Volkswagen did not agree to pay these fees and costs as part of the Settlement, and because Non-Class Counsel have not offered evidence that their services benefited the class, as opposed to their individual clients." Id. Such lawyers could, of course, recoup fees from individual clients with whom they had retainers. Id.

72. See, e.g., Delaware Coal. for Open Gov't, Inc. v. Strine, 733 F.3d 510, 521 (3d Cir. 2013), cert. denied, 572 U.S. 1029 (2014); N.Y. Civil Liberties Union v. N.Y. City Transit Auth., 684 F.3d 286, 297 (2d Cir. 2011). 
documents" to which access is constitutionally obliged. ${ }^{73}$ Support for post-decision access comes from understanding that the First Amendment obliges that monitoring and distribution filings made about class and MDL settlements are part of the judiciary's records and are open to the public.

One final return is therefore in order to the insights in Abbe Gluck's and to the Clopton/Rave papers about the impact of federalism on aggregation. Federalism demonstrates the capacity to sustain toleration within polities of plural legal norms. The effort to respect variations while adhering to certain specified legal obligations is what aggregate proceedings need to embrace. Federalism is predicated on the propositions that more than one legal regime is permissible, that individuals have multiple political affiliations and layered citizenship identities, and that sources of law are plural. To be true to its grounding in the complexity of the federalism of the United States, the opioid litigation needs to look for multiple ways to achieve stages of partial, phased, or staged "peace" so that those living now with the harms can have resources and ways to move forward.

73. Compare United States v. Erie Cty., 763 F.3d 235, 243 (2d Cir. 2014) (requiring access to a monitor's report related to jail conditions), with IDT Corp. v. eBay, 709 F.3d 1220, 1224 (8th Cir. 2013) (declining to require access), and SEC v. Am. Int'l Grp., 712 F.3d 1, 5 (D.C. Cir. 2013) (holding that reporters had no common law or First Amendment right of access to reports ordered to be provided by an independent consultant, dispatched pursuant to a court decree). See generally Judith Resnik, The Contingency of Openness in Courts: Changing the Experiences and Logics of the Public's Role in Court-Based ADR, 15 NEv. L.J. 1631 (2015). 
430

DEPAUL LAW REVIEW

[Vol. 70:407 